\title{
Note to the Reader
}

In the text, Old Norse phrases and citations will not be Anglicized, but the thorn will be represented by "th" and a hooked "o" will be written as ö. Writing in English about the medieval Norse, one must decide whether their names should conform to Old Norse or to English practice (for example, Eiríkr vs. Eirik or Eric; Guðriðr vs. Gudrid). With a few exceptions, the present book spells medieval Norse personal names and place names in the Anglicized or "normalized" manner, omitting whenever possible the acute accent. (Although helpful in indicating a long vowel, in Old Norse and modern Icelandic this same diacritical mark is also used to indicate a different sound to the vowel altogether and thus requires the reader to know the pronunciation rules.) The names of modern Icelandic authors will nevertheless observe all diacritical marks to aid name recognition for bibliographical purposes.

In the Index, medieval Norse names will be listed alphabetically by first names followed by the patronymic (for example, Leif Eiriksson), but postmedieval Nordic authors-including Icelanders - will be listed under their last name both here and in the Bibliography. Please note that the latter contains only the works I have actually cited in my text; it does not include background reading.

In the vast literature that now exists concerning the Vínland Map, there is considerable variation in the spelling of personal names, literary titles, and place names. In direct quotes, the writer's own preference will be observed, but I have otherwise made an effort to impose some uniformity. In particular, the reader needs to be forewarned that except when quoting other writers, I use the form "Vínland" to indicate the long vowel sound. Scholarly battles have xxi been fought over less! 

Maps, Myths, and Men 
